\title{
Correction to: Myelin oligodendrocyte glycoprotein antibody- associated disease: characterising clinical disease
}

\author{
M. D. Willis ${ }^{1}$ - N. P. Robertson ${ }^{1}$
}

Published online: 27 August 2018

(c) The Author(s) 2018

\section{Correction to: Journal of Neurology (2018) 265:1950-1952 https://doi.org/10.1007/s00415-018-8963-z}

The original version of this article unfortunately contained a mistake. The copyright line was incorrect in the HTML version. The correct copyright line should be "The Author(s) $2018 "$.
Open Access This article is distributed under the terms of the Creative Commons Attribution 4.0 International License (http://creativeco mmons.org/licenses/by/4.0/), which permits unrestricted use, distribution, and reproduction in any medium, provided you give appropriate credit to the original author(s) and the source, provide a link to the Creative Commons license, and indicate if changes were made.

N. P. Robertson

robertsonnp@cardiff.ac.uk

1 Institute of Psychological Medicine and Clinical

Neuroscience, Cardiff University, University Hospital

of Wales, Heath Park, Cardiff, CF14 4XN, UK 